\title{
Rural Schooling and Good Life in Late Socialist Laos
}

\section{Articulations, Sketches and Moments of 'Good Time'}

\author{
Roy Huijsmans \\ International Institute of Social Studies, Erasmus University, \\ Rotterdam, The Netherlands \\ huijsmans@iss.nl
}

Mr Piti

\begin{abstract}
Drawing on ethnographic research in northern Laos, this article analyses articulations of a good life in primary school textbook imagery and how this resonates with everyday life in rural upland communities. This is contrasted with children's sketches of a good life found in the classrooms and ethnographic accounts of moments of 'good time' in the context of rural schooling. It is argued that these latter moments constitute brief instances of a good life in the present. Given the deeply hierarchical power relations in which rural education is embedded, not all of these good times stay good for very long. This is reflective of the condition of late socialism in rural areas.
\end{abstract}

\section{Keywords}

Laos - good life - children - school - textbooks - rural

The social condition of late socialism in East and Southeast Asia is shaped by a number of intersecting transformations. In the case of Laos, these transformations are perhaps most visible in rural areas and include large-scale infrastructural projects such as the China-Laos railway construction (Rowedder 2020), hydro-power projects (Blake and Barney 2018), land concessions and land closure for environmental protection (Ducourtieux et al. 2005; Baird 2011) and village relocation and resettlement (Evrard and Goudineau 2004). These devel- 
opments are all centrally planned in a one-party Leninist political system that leaves very little space for dissent. While 'authoritarian rule' thus characterises Lao state power and authority, so does the descriptor of 'weak state capacity' (Creak and Barney 2018: 693-694). This leaves an empirical question: how, precisely, do these large-scale developments pan out in specific local contexts within Laos? Nonetheless, the booms and busts of transnational capital are increasingly marking Laos' physical and social landscape, yet the phrase 'late socialism' used in this article serves to emphasise that this has not led to any significant changes in the political system and associated set of ideas.

Since notions of the good life are part of a system of ideas (Appadurai 2004: 67 ), the condition of late socialism is particularly fertile ground for furthering debates on the good life because, in late socialism, systems of ideas have become manifold and are in a constant state of flux. Furthermore, the Lao paradox of authoritarian rule exercised through a state system with a relatively weak capacity (Creak and Barney 2018) raises questions about how statesanctioned articulations of the good life actually reach the populace in remote, rural locations, but also emphasises the importance of going beyond statecentric analyses. With regard to the latter, this article makes a case for attending to situated practices or, more specifically, practices through which moments of good time unfold. It is shown that these instances of good life in the present may not stay essentially good, or at least not necessarily for all involved. This way, it is argued, those involved come to experience the contradictions of late socialism in Laos in a highly situated and intimate manner.

Empirically, this argument is developed on the basis of research on rural schooling in northern upland Laos. Compared to the transformations listed above, in the Lao context education has attracted much less critical scholarship. Yet the expansion and intensification of basic education that can be observed across rural Laos has certainly not been any less impactful. Moreover, the location of schooling on the intersection of state and society renders it a space in which various ideas of a good life are articulated, reworked, negotiated and possibly resisted (Morarji 2014; Dungey and Ansell forthcoming).

A focus on the productive function of rural schooling does not seek to deny the many problems that continue to characterise rural schooling in much of the Global South. This includes poor learning outcomes (Nag et al. 2016), meagre infrastructure, difficulties of realising quality teaching and attracting qualified teachers (Mulkeen and Chen 2008), its poor fit with rural life (Ansell et al. 2018), and the politics of language of instruction (Christie 2015). Indeed, these issues can easily be identified in rural Laos too (e.g. UNICEF and MoES 2015). Yet that does not take away from the fact that in present-day, rural, remote Laos 
a primary school ${ }^{1}$ is easily found, there will be a teacher representing the modern ideal of uniformed, educated, salaried employment (but who is probably also involved in commercial activities besides her/his teaching job) and most children receive a few years of education during which they are exposed to state-sanctioned ideas of a good life. All this was far from the norm among the parents of today's students (see also Gerber and Huijsmans 2016). In addition, more so than a generation ago, in remote, rural Laos children bring to the school alternative ideas of a good life which have reached them, for example, through migrating peers and digital media (Huijsmans and Trần 2015).

The research presented in this article was conducted as part of a ESRCDFID funded project titled 'Education Systems, Aspiration and Learning in Remote, Rural Settings' (2016-2018). ${ }^{2}$ Although this is a three-country study with research sites in remote rural settings in India and Lesotho too, this article is limited to the Laos component of the project. In the next section the article is theoretically grounded. It continues with a description of the methodology used before presenting our empirical material comprising of an analysis of articulations of a good life made through textbook imagery as well as ideas of a good life transpiring from children's artwork found in schools. This is complemented with an analysis of ethnographic descriptions of moments of good time observed during our school-based ethnography in upland northern Laos. The article concludes by relating our findings to the conditions of late socialism.

\section{Schools and a Good Life: Philosophies, Articulations, Sketches and} Practices

Education features centrally in ideas of a good life and does so at different scales. At a global scale, international development agendas have long embraced education as a key ingredient for realising better lives. For example, the now expired Millennium Development Goal 2 and the current Sustainable Development Goal 4 are squarely about education. Despite the widespread consensus on the importance of education there are, however, notable differences in how, precisely, it relates to a good life. For example, for Sen, education

1 Admittedly, these may be 'incomplete' schools that do not offer the full (five grades) primary education cycle.

2 Funded through the ESRC-DFID Raising Learning Outcomes in Education Systems (grant number: Es/No1037X/1), PI: Professor Nicola Ansell, Brunel University London, United Kingdom. 
is intrinsic to a good life (Sen 1999). Sen's capability approach is underpinned by a liberal idea of the good life. From this philosophical position, realising a good life is about maximising the range of choices one has reason to value. Education, thus, is key to his idea of 'development as freedom' (Sen 1999). Education may also be seen as instrumental to realising a good life. This is most notably the case in relation to human capital theory, another key paradigm in development thinking, especially in relation to education and the young (World Bank 2006). The logic of human capital theory posits that education increases productivity and competitiveness. At an individual level this means that the human capital acquired through education enhances one's employability. The status conferred by being in successful self- or salaried employment might be a form of good life in and of itself, but the link to a good life may also be realised through the increased income resulting from this and the consumption and associated lifestyle it permits.

These globalised philosophies of a good life inform many an education system. In addition, education systems may also reflect more regionally rooted ideas of a good life. The notion of buen vivir/vivir bien (literally: 'good living' or 'living well') is the case in point. It refers to various understandings of good living originating from indigenous peoples of the Andes revolving around core concepts including 'nature, community, labour and Ayllu, consensus and democracy, spirituality', and key principles such as 'reciprocity, complementarity and relationality' (Villalba 2013: 1439). The educational reforms implemented under the Morales administration in Bolivia, for example, reflect the notion of vivir bien (Lopes Cardozo 2012: 759-76o). More commonly, though, state-provided mass-schooling reflects more national(ist) ideas of a good life (Lall and Vickers 2009). This is evident from the content of the curriculum, teaching aids, the decoration of the classroom, as well as from various national rituals that are often part and parcel of everyday school life (Evans 1998; Cheney 2007; Benwell 2014; Moser 2016). Finally, education is not just filled with global-, regional- and national-level notions of a good life, it also features in poor people's own imagination of a good life. For example, for adults and children alike education continues to constitute a beacon of hope through which they seek to realise a better life (Jakimow 2016; Kaland 2021; Dungey and Ansell forthcoming).

The various relations between education and a good life inform how education, in the form of schooling, is organised as an institution as well as the concrete forms it takes in practice. Since the provisioning of education is a national affair, state-sanctioned ideas of a good life are typically most easily observed and most fully expressed. Therefore, these are referred to here as 'articulations'. Yet the state does not determine what happens in the classroom: 
there are teachers and students too. Our data show that students are not just the targets of intervention of compulsory mass-schooling: they also engage in their own practices of future-making while at school. This may not amount to a coherent account of a good life on par with the state-sanctioned 'articulations'. Rather, these are rough drafts found in the margins of the classroom. They are referred to here as 'sketches of a good life'.

In this article these two future-making dimensions of schooling are juxtaposed with a focus on the school as a site of practice. This shifts attention to activities unfolding in the present, which expands the conventional scope of studying ideas of a good life, theoretically on the basis of Berlant's (2011) Cruel Optimism. In this book, she theorises about practices one chooses to engage in because they bring one closer to something one longs for, be it upward social mobility or recognition. Yet she argues that one's very attachment to such practices can be cruel because they often do not help one in actually getting there, or may even get in the way. Although Berlant writes from a US perspective and bases her argument on a critical reading of cultural material produced in the West, this article would suggest her work is good to think with in relation to rural schooling in the Global South too. In Berlant's terms, children's everyday school attendance can be understood as an optimistic attachment. Rural children and their parents attach themselves to the idea that schooling can bring them 'closer to satisfying something' (Berlant 2011:1-2) that they cannot realise on their own (see also Jakimow 2016).

Berlant's work also helps in theorising the spatial dimension of rural schools as sites of practice of a good life. In remote rural settings, schools are a place of distinction in a number of ways. Often, rural schools are the only constantly present and visible mark of the state. In addition, school life contrasts with village life on a number of accounts including its temporal organisation (the role of clock time), its generational structure (age-graded classroom organisation and teacher-student relations), in an embodied manner (e.g. school uniforms and other forms of bodily disciplining such as hairstyles, footwear, clean nails, etc.) and in relation to the nature of work (non-manual work and teachers are in salaried employment). For its main actors, children and teachers, mere participation in the everyday practice of school constitutes a break with village life at large and an engagement with a good life. Involving oneself in various school activities holds the promise that this other and better life can be sustained more permanently. The uniformed teachers with their salaried positions and completed education are the living examples of this. On this basis, everyday school attendance can be conceptualised as 'nearness' to a something that 'will help you or a world to become different in just the right way' (Berlant 2o11: 2). 
These theoretical premises led to zooming in on moments of 'good time' that were observed unfolding as part and parcel of schooling as everyday practice. These are moments in which one is close to a good life. But as it goes, not all good moments stay good or are inherently good. As this article goes on to argue, these moments can easily become cruel as people become aware of the limitation of their possibilities within the social system of which they are a part precisely in instances when the contours of social divisions appear to have given way. Furthermore, there is also a generational argument for looking at school-based practices taking place in the present. After all, for students, teachers provide a glimpse into what the future, and by implication a future good life, might look like. So even if children themselves observe these moments of good time only from a distance, from their perspectives these can be read as concrete manifestation of a possible future good life, including its cruel footnotes.

\section{Methodology and Context}

The research material presented in this article was collected as part of an ESRCDFID funded project. As with all international research conducted in Laos, we collaborated with a Laos-based partner organisation: the Laos office of PLAN International, whose activities were demarcated through a Memorandum of Understanding with the Lao Ministry of Education and Sports. Consequently, as researchers we had little control over the choice of study sites and we ended up conducting the research in two target villages for an early childhood education programme run by PLAN International in a northern Lao province. Throughout, our research was carefully monitored by officials from the District Education and Sports Bureau (DESB).

The two study villages are referred to using the pseudonyms Baan Nyai, for the larger village (nearly 140 households), and Baan Noi, for the smaller village (nearly 70 households). Baan Noi has a majority ethnic Hmong population and Baan Nyai a majority ethnic Khmu population, both complemented by residents of various other ethnic groups (e.g. Lao and Lue). ${ }^{3}$ Baan Noi has a full primary school (five years) only, a few household-based shops and few other

3 Consistent with the national slogan of 'the multi-ethnic Lao people' (see below), the government of Laos refrains from using the phrase 'ethnic minority/ies' and instead uses the term 'ethnic group' (son phao). This phrase is used here too, although our analysis problematises the idea that these ethnic groups are indeed all equal in relation to the politics of representation. 
facilities. Baan Nyai has a full primary school, a partial secondary school that will grow into a full secondary school (seven years) in the near future, and more and larger shops.

The two villages are rural sites, but their degree of remoteness is relative. Both villages can be reached by car and motorbike virtually throughout the year. Depending on the season this takes a two- to four-hour drive from the district centre. Their location on the road network renders these villages less remote than many others in rural Laos, where access may be by foot and/or small boat only. Further, over the course of the research the remoteness of the research setting changed substantially. There were Chinese engineers in the district capital at the onset of the fieldwork part of the research in early 2017, and by the end of the project (early 2018) Baan Nyai had become home to a sizeable labour camp providing accommodation to about 100 Chinese construction workers working on the Lao-China railway project. The presence of these male Chinese labourers not only affected social life in the village: the works also transformed the infrastructure beyond the railway. For example, the road running from the district centre to Baan Nyai was upgraded significantly in order to allow the passing through of heavy machinery. At a more micro-level scale, the petanque court in front of the teachers' houses was upgraded noticeably by using cement blocks discharged by the Chinese workers to demarcate the court, and some young men had found casual employment as drivers for the Chinese railway project, while children and young people made some money by selling chickens and vegetables to the labourers.

Per the requirements of the Laos-based partner organisation hosting the research (Plan International Laos), the bulk of the data collection was conducted by a Lao national researcher who uses the pseudonym Piti. Mr Piti visited the two study villages regularly between January 2017 and August 2017, complemented by a few additional project visits afterwards (the last one in March 2018). The fieldwork took the form of village stays during which $\mathrm{Mr}$ Piti used a range of methods, including participatory research activities with children (e.g. drawing, role play, etc.), qualitative interviews with children and young people as well as adult villagers, a household survey and classroombased observations. The first author accompanied Mr Piti on some of these research trips. With a few exceptions, Mr Piti was always accompanied by a DESB official. This was formally explained as necessary for protecting his security, but more plausibly it was to enable the Lao state to keep a close eye on this foreign-funded research project conducted in an upland area populated by mostly non-Lao ethnic groups (Creak and Barney 2018, 696). The advantage of this arrangement was that we were in a privileged position to observe the 
working of state-society relations at this very local level and across the various social divides in which these are embedded (Singh 2014).

This article draws on an analysis of the visuals in Lao primary school textbooks and village- and school-based ethnography. The accounts of 'good time' presented are drawn from our ethnographic fieldnotes and children's sketches of a good life collected during our classroom-based observations. The idea of schools as sites in which state-sanctioned ideas of a good life are articulated is developed on the basis of textbook analysis. Compared to teacher guides which are consulted only rarely and selectively, let alone followed, the ideas presented through textbooks reach most students and do so in a fairly unmediated manner.

\subsection{A Note on Textbooks}

In the rural Lao context most students have access to their own set of textbooks which they are allowed to carry home. For students in the poorest districts (and the two study villages are located in one such district) access to textbooks is free of charge. ${ }^{4}$ International development actors have funded textbook development projects, making textbook shortages, at least at primary school level, a thing of the past. For international development actors, funding textbook production (and revisions) is attractive because it constitutes a clearly demarcated intervention with obvious deliverables. The problem of textbook shortages has also lessened because of curricular reforms that have led to the bundling of subjects, reducing the number of textbooks children use at primary school level. In addition, the cost of printing and distribution of textbooks has dropped. An additional argument for focusing on textbooks is that, because of global, and donor-embraced, shifts in pedagogical approaches, primary school textbooks have become less text-heavy and increasingly feature colour-printed images of reasonable to good quality. This means that even if primary education systems do not succeed in equipping (rural) students with basic literacy and numeracy skills, as is indeed often the case in rural Laos (UNICEF and MoES 2015), students are still exposed to the articulations of a good life conveyed through primary school textbook imagery.

The illustrations in the Lao textbooks are produced by artists linked to the School of Lao Fine Arts. In line with Koshcheeva's analysis (2020,33) of the Lao arts, the artwork included in school textbooks must be appreciated 'as a product of the alignment between artists and the authoritarian state' and fits within the genre of neo-traditional arts promoted by the Lao state. An interview with

4 Students effectively borrow the textbooks and return them at the end of the school year. 
one of the artists working on textbook illustrations showed that artists are well aware of the conventions within which they are expected to work when producing such illustrations. When talking about his work, this relatively young Vientiane-based artist explained he had taken over the task of drawing textbook images from a senior colleague at the School of Lao Fine Arts. He showed us around in his gallery, where he was experimenting with various art forms. When we asked why he did not use any of this for his work on textbooks, he explained that if he were to depart from the established convention his work would simply not be approved by the Lao government office in charge of textbook production.

This article focuses on the textbook series combining the subjects 'Moral Education' and 'The World Around Us' of the full primary school cycle (Primary 1 through to Primary 5). The imagery in this textbook series represents the Lao state's articulation of a good life. Yet this leaves open the question of how children understand these images. Bayly's research (2020) on images and moral citizens with adults in Hanoi, Vietnam, sheds light on why it is so difficult to get to people's own understanding of state-produced images in contexts of late socialism-especially those used in school textbooks. According to Bayly, for her Hanoian respondents to admit that one is not clear about the meaning of lessons or images in moral education textbooks, or to point out any contradictions or alternative interpretations, is neither valued nor regarded as 'a sign of cleverness' (Bayly 2020, 1582). Rather, it means the individual is at fault in the sense of 'I've failed to prepare properly and can't work out what I should have seen' (Bayly 2020, 1583). Therefore, in classroom spaces where the emphasis is on 'getting it right', 'silence is a choice: a best option and an agentive one' (Bayly 2020,1582 ). Bayly's insights from Vietnam were reflected in our work with children in rural Laos. Seeking to overcome the problem of 'getting it right', we have experimented with creative and participatory methods including drawing activities, role play and having children design their own timetable. The participating students seemed to enjoy these alternative forms of classroom work but struggled to express themselves more openly. For example, the timetables designed by children themselves largely reflected their regular timetable and the role plays they enacted were fairly realistic reflections of everyday school life. In spite of this, careful observation of the classroom environment did yield some evidence of children imaging alternative ideas of a good life which are discussed after the following section. 
When analysing representations of a good life featured in primary school textbooks, it is important to acknowledge that textbooks are typically written from the centre. As such, the texts, illustrations and exercises are often urban or even capital-city centric. With that in mind Lao primary school textbooks stand out because a conscious effort appears to have been made to be inclusive of rural life too.

Laos can be described as a 'development context', which in the words of Jakimow $(2016,11)$ is a locale that is 'thick with the discourses, practices and institutions of international development'. The inclusiveness of rural life in primary school textbooks presents a subtle nuancing to dominant development discourse in Laos, which is urban-centric and revolves around the idea of prosperity (chaleun) and progress (khaonaa) (Singh 2014). The inclusion of rural scenes in primary school textbooks is no doubt also influenced by the neotraditional arts genre promoted by the Lao state. Still, the very inclusion of images of rural life is no small matter. It conveys the important message that a good life can be a rural life too. This counters the dominant development narrative which renders rural spaces as backward and in need of development (Rigg 2005: 83; Huijsmans et al. 2021).

However, with a closer look at the particularities of representation this general statement requires some nuancing. Indeed, Koshcheeva $(2020,58)$ observes, about Lao neo-traditional arts, that 'it is not an accurate depiction of the country's condition or events that the artwork presents but rather a dream of rural romance-happy people with a rich and authentic culture, immersed in the perpetual performance of tradition'. An illustration and accompanying exercise in the 'World Around Us' part of the Primary 1 textbook is representative of the way a rural good life appears throughout the textbook series (RIES 2013,61 ). The picture is a colour image, drawn in a realistic style (see Figure 1 ). The caption above the drawing asks the students 'What do you see in this picture?' (nakhian hen nyang dae nai houpnii?). What is depicted is a rural scene with untouched, unpopulated, green hills in the background. There are rice paddies in the plains in front of the hills, and adjacent to this there is a tidily organised village consisting of clusters of houses separated by neatly maintained dirt roads, with some coconut and other trees here and there. The houses in the village are traditional lowland Lao houses, built on wooden stilts, with walls of plaited bamboo mats and grass-thatched roofs. There are four concrete buildings in the image: an impressive (relative to the village) Buddhist temple, a primary school with a flagpole in the centre of the fenced school grounds flying the Lao national flag, a health centre and one more concrete building, which is 


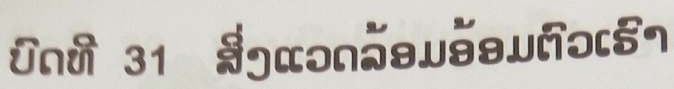

1 บัภธรบเขับซยยัวณก่ใบธูบบิ้ ?

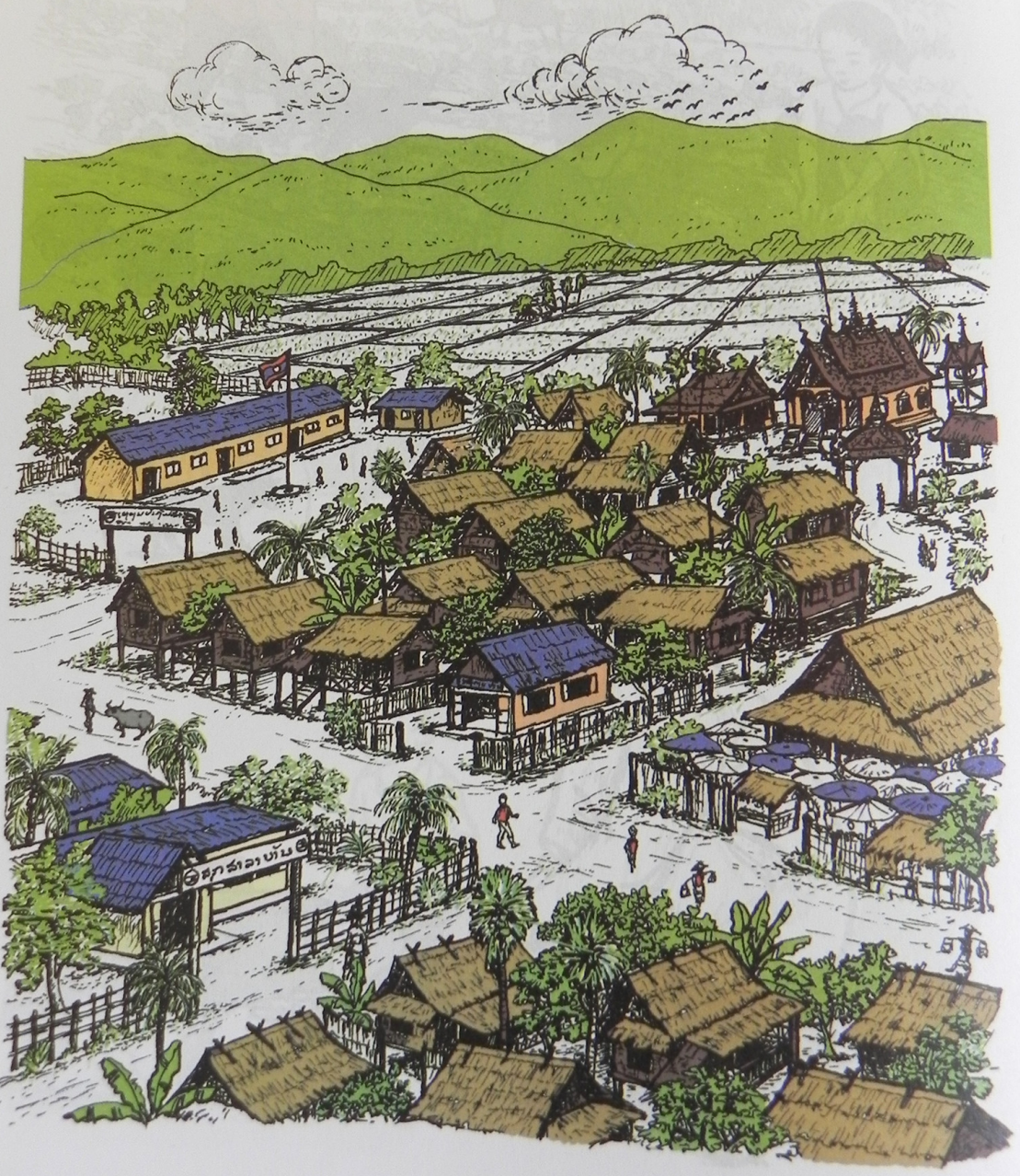

FIGURE 1 Representation of rurality in Lao primary school textbook 
most likely the village office (hong kaan baan). There are children in the school grounds, itinerant vendors on the main road running through the village and a farmer with a buffalo.

This description generates some important qualifications about the way in which a good rural life is depicted in Lao textbooks. First, it must be understood as a very particular form of rural inclusion: it is largely a lowland, Buddhist, ethnic Lao version of rural life. Second, the rural good life that is represented must also be recognised as a romanticised rural idyll, which stands in friction with the more material aspirations of a good life documented in ethnographic studies of rural Laos (High 2014; Stolz 2019).

The bias towards lowland rural scenes in textbooks means that hills and mountain slopes feature at best as a background to the good life, and at worst as sites that are a danger to the good life that is proposed. With regard to the latter, the few textbook images which show that hillsides are inhabited and used productively (e.g. trees are cut, land is cleared by using fire, wildlife is hunted) are without exception used in lessons about harmful practices, detrimental to a good life because they destroy the environment (e.g. RIES 2015b, 95, 150; RIES 2015a, 103; RIES 2016, 213). Since shifting cultivation was practised by most of the parents of the children in the study, these children are caught between different systems of ideas and related versions of a good life: the one that is articulated in textbooks and the one that sustains their families. Problematically, while textbooks ask children to reflect on the various problems attributed to shifting cultivation (their parents' economic mainstay), these textbooks do not propose or stimulate any alternative suggestions of a rural good life that is positively inclusive of upland rural spaces. ${ }^{5}$

The partial representation of Lao rurality intersects with an ethnic dimension because in Laos the hills and mountainsides are mostly populated by various ethnic groups other than the Lao. Again, Lao textbooks must be complimented for incorporating a degree of ethnic inclusion, but also here it is a partial inclusion. This is best illustrated by an image of an ethnic Hmong family in the 'Moral Education' section of the Primary i textbook (RIES 2013, 11). The father and mother are enjoying time with their daughter, who is playing on a swing (Figure 2). The houses in the background are indeed drawn in a way that

5 The possible exception is images of children belonging to ethnic groups other than Lao engaged in tree-planting activities in upland areas (e.g. RIES 2015b, 46). Regardless of the economic viability of such practices, such representation amounts to a 'limited legitimacy' of upland communities (as protectors of the natural environment) which delimits the claims they can make to a larger share of the natural resources (Walker 2001). 


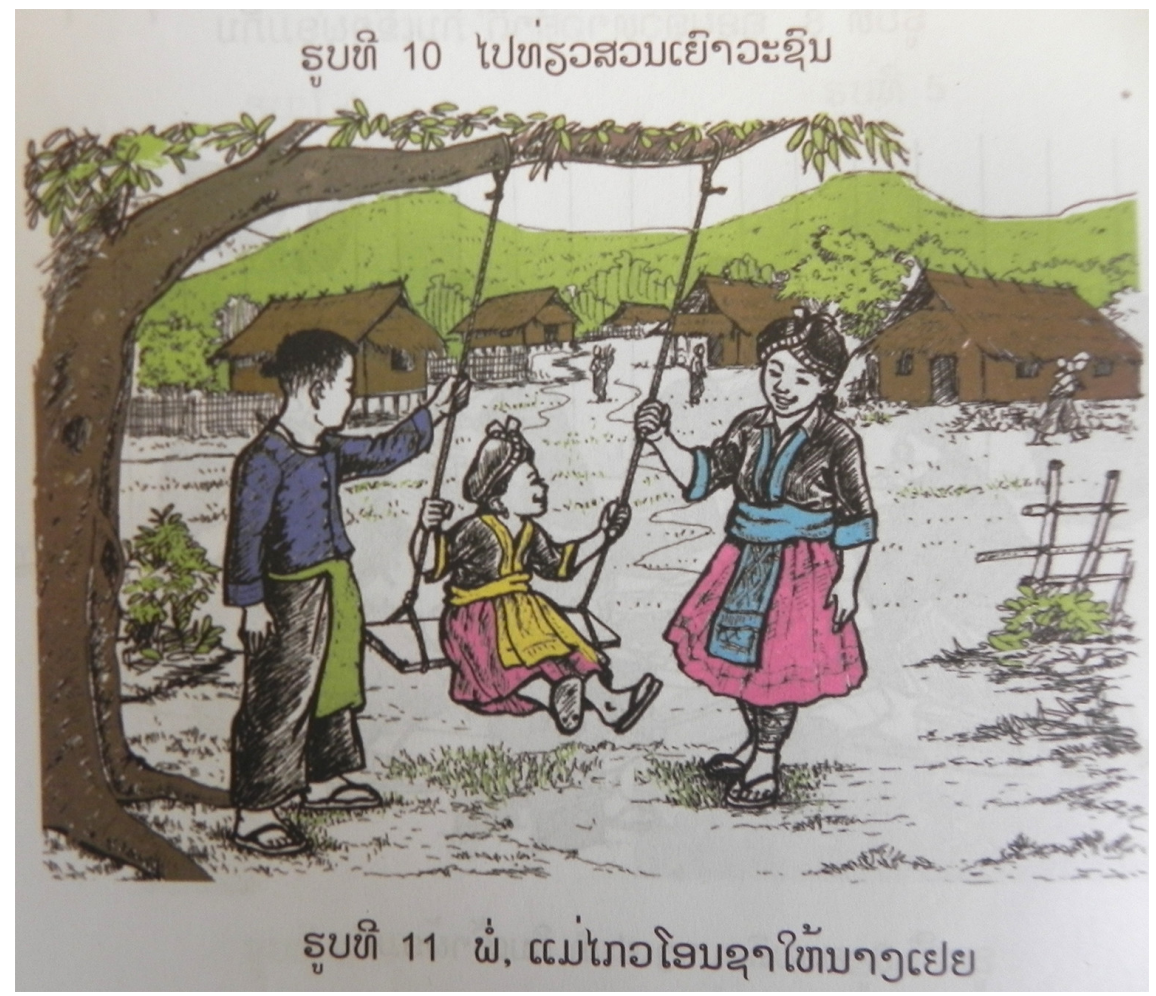

FIGURE 2 Ethnic inclusion in Lao primary school textbooks

is representative of how Hmong houses in rural villages often look (compare with the houses on stilts in Figure 1 representing traditional ethnic Lao architecture). Yet here too the mountain slopes are a green, untouched background. This mutes the economic mainstay for many Hmong families and other ethnic groups (e.g. Suksavang Simana 2003) residing in upland Laos: shifting cultivation. Therefore, the ethnic inclusion demonstrated in Lao textbooks appears shaped more by an interplay between the politics of ethnic representation in Laos (Pholsena 2002) and the government of Laos' development policies that seek to halt shifting cultivation through encouraging permanent forms of agriculture and establishing protected forests (Vongvisouk et al. 2014, 2), and much less by an accurate representation of livelihoods practised by ethnic groups in upland areas. Similarly, the fact that in the 'Moral Education' part of the textbook series fifteen of the twenty-seven images clearly featuring people from ethnic groups other than the ethnic Lao also include ethnic Lao people reflects the state's desire to foster 'ethnic solidarity' captured by the slogan pasason Lao banda phao ('the multi-ethnic Lao people') (Tappe 2007, 
98). ${ }^{6}$ This national slogan is perhaps best illustrated by the image of three girls studying together in the 'Moral Education' section of the Primary 4 textbook (see Figure 3). The image accompanies a lesson with the title 'Solidarity between all ethnic groups' and presents a story of the three girls entitled siewhak, which can be translated as 'close friends' ('close as kin'). These two headings of the lesson weave together socialist language (solidarity), nationalist language (ethnic groups) and everyday intimate expressions (siewhak for 'close friends'). As is the case for other state-produced images of Laos' ethnic diversity (Huijsmans 2019), here it is also reduced to three ethnic groups: the ethnic Lao (represented by the girl on the left), the ethnic Hmong girl (represented by the girl in the middle) and the ethnic Khmu (represented by the girl on the right) (RIES 2015b, 44). ${ }^{7}$ The accompanying lesson elaborates the ideal of good inter-ethnic studentship by telling a story of friendship and how these students help each other in their studies. ${ }^{8}$ However, the image also sends a subtle message of hierarchy between ethnic groups. After all, it is the ethnic Lao girl who is explaining the lesson to her peers. Despite these critical remarks it is acknowledged that the partial and particular inclusion of ethnic diversity also has a positive effect. For example, when discussing a similar image in the Primary 1 textbook with a group of Hmong students it was noteworthy that the students remembered without effort the name of the Hmong girl featuring in the lesson (for which a common Hmong name was used) but had forgotten the name of the ethnic Lao children, even though the name of the Hmong girl was only mentioned in the caption of the picture while the other names appeared throughout the lesson.

Finally, the image of the rural scene (Figure 1) subtly sends a message about the drivers behind transformations in the countryside. In this image, the villagers live in traditional Lao houses. In contrast, all state buildings (the school,

6 The Moral Education parts of the textbooks included a total of 329 images across the five years. The share of images clearly including representations of people of ethnic groups other than Lao ranged from 8 to 14 per cent across the five years.

7 This is reminiscent of the Lao Lum (valley Lao), Lao Theung (Lao of the mountain slopes), Lao Sung (Lao of the mountaintops) ethnic classification, dating back to the colonial era (Pholsena 2002, 180). While officially disregarded and replaced by new systems of ethnic classification, these phrases remain widely used in everyday speech.

8 Next to messages about harmony and equality between ethnic groups, the textbook imagery also stands out for its insistence on gender parity. Virtually all images that include more than one person are carefully balanced, with as many girls or women as there are boys or men. Furthermore, some of the images stimulate students to question gendered stereotypes. For example, the Primary 5 Moral Education text (RIES 2016, 29) includes an image of a woman acting as a village chief (naibaan) even though most village chiefs are men. 


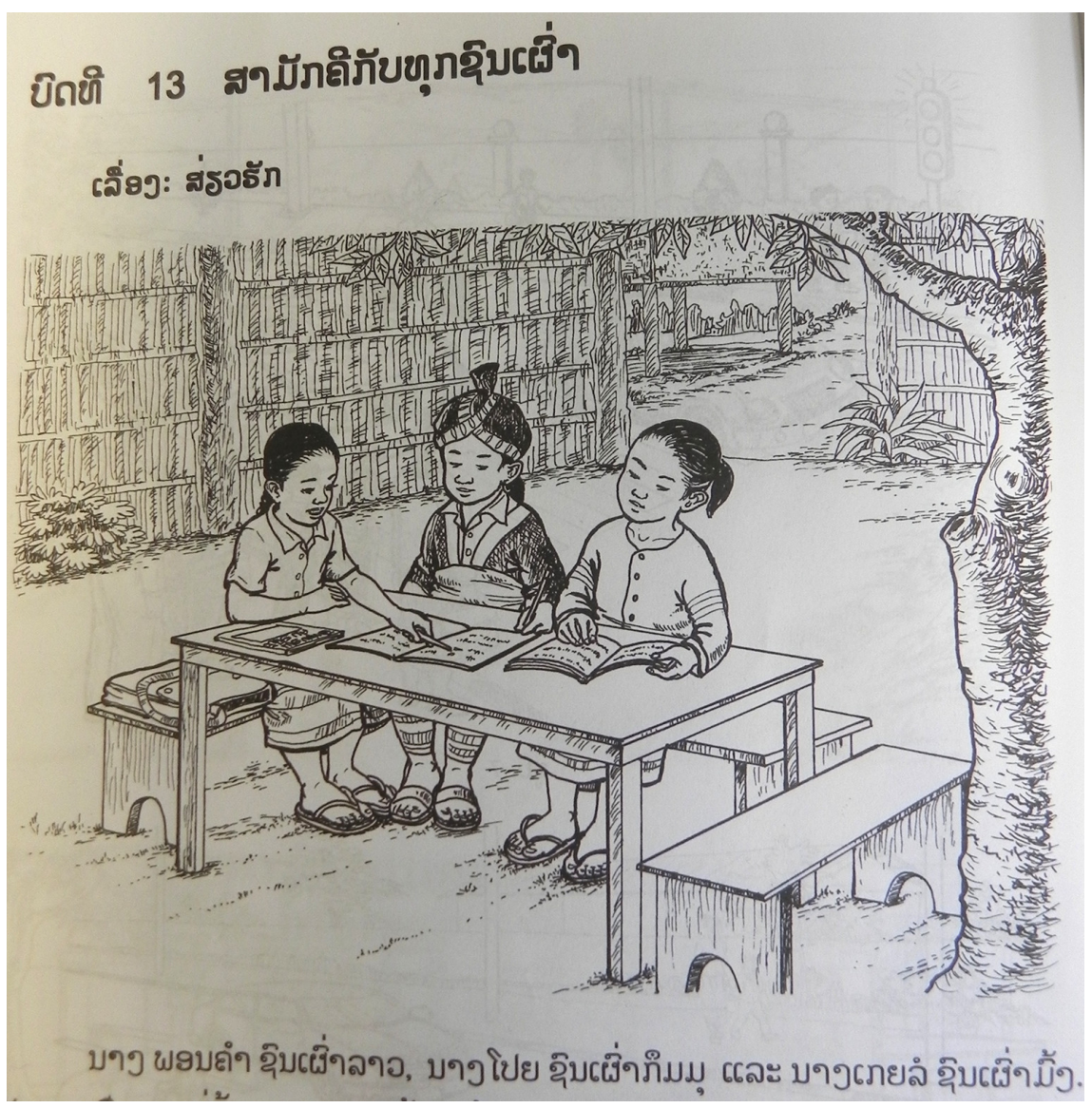

FIGURE 3 Representing good inter-ethnic studentship in Lao primary school textbooks

the health centre, the village office) represent modern architecture: low-rise concrete structures. The image thus suggests that the state is the agent of change, a model which villagers over time may emulate. Unsurprisingly, such a state-centric reading of how change happens is over-simplistic, even in Laos where the Communist Party has remained firmly in power for almost half a century. For example, the work of Stolz (2019) on 'housing aspirations' in an upland ethnic Khmu community in rural Laos illustrates that, rather than officials, it is ordinary villagers whose cross-border migration experiences have changed their ideas about the housing dimension of a good life. 


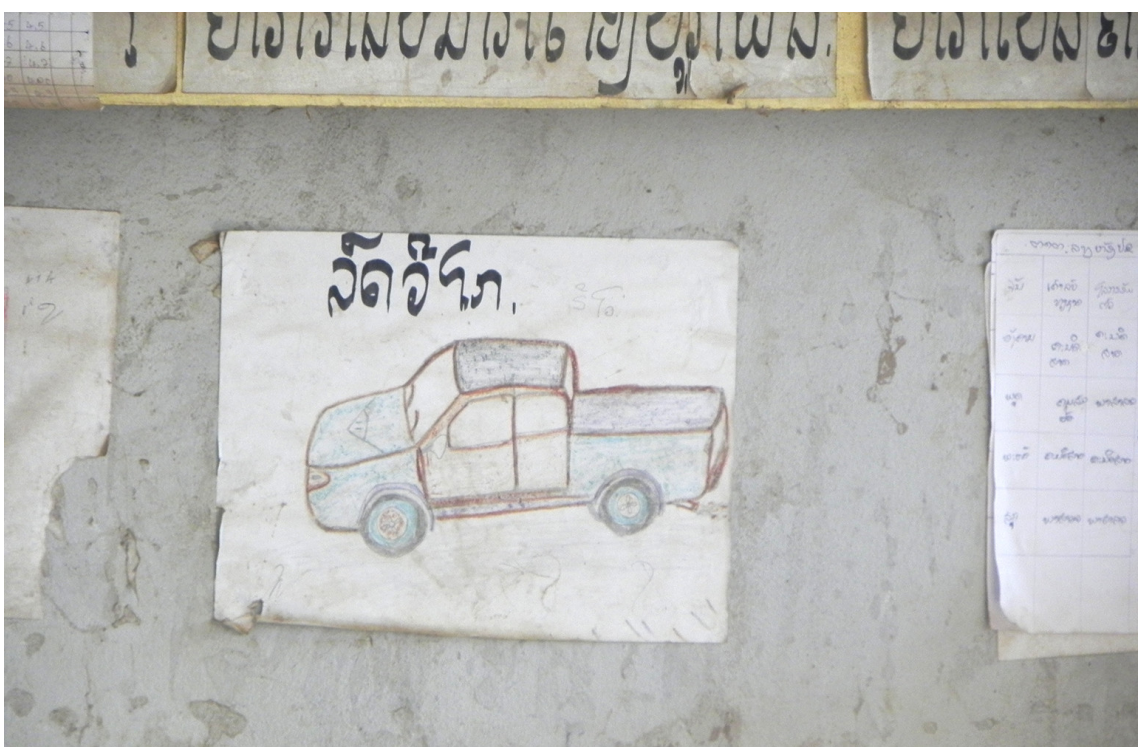

FIGURE 4 Students' sketches of a good life (Baan Noi)

The Lao school system does not leave much space for children to express nonconforming ideas of a good life. This does not mean that children do not do so. Rather, they were just less visible to us as researchers.

A first example of an aspect of a good life expressed by one of the students, and different from what is articulated in textbooks, is a drawing (Figure 4) found on the wall of one of the classrooms in Baan Noi. The drawing features a Toyota Vigo, a popular pick-up truck in rural Laos (and beyond). The drawing was put up in the classroom and carried the teacher's writing (lot vigo in Lao script) at the top of the drawing. This suggests that the teacher has approved of this more material and individualistic expression of a good life. Notably, Vigo has also emerged as a name that parents give to their children. At least one boy in Baan Noi used the name Vigo in addition to his Hmong name.

Another sketch of a good life was found on the seat of a stool used in one of the three classrooms comprising the Baan Noi primary school. It is a drawing of a fashionably dressed young woman (Figure 5).

A similar drawing was found in one of the classrooms in Baan Nyai. Unlike the case in Baan Noi, here the drawing was put on display on the classroom wall, suggesting that the teacher approved of it (Figures 6 and 7). As Figure 6 illustrates, the work was part of a series of similar artworks (all produced by girls). 


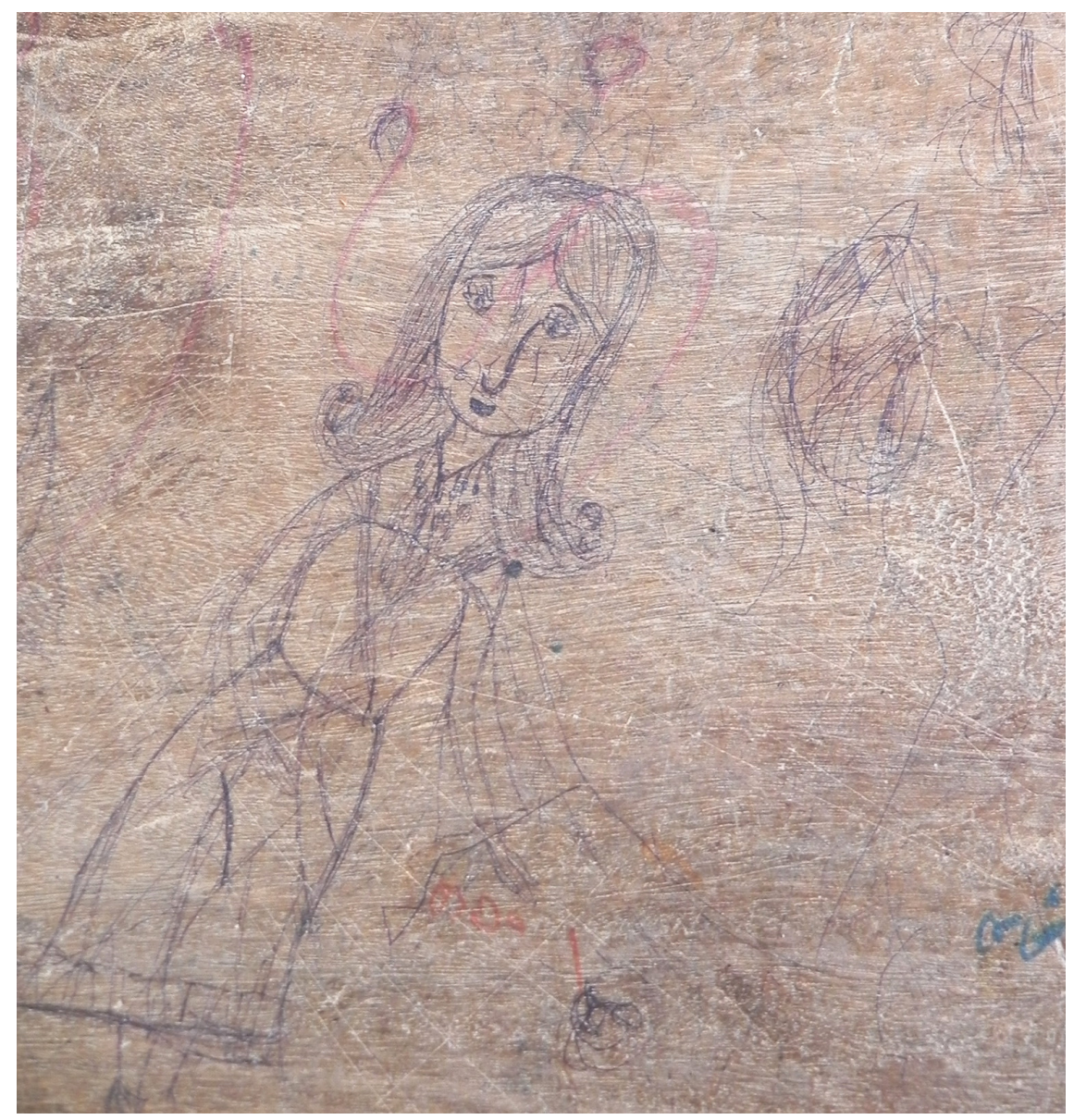

FIGURE 5 Student's hidden sketch of a good life (Baan Noi)

The women in these drawings are all fashionably dressed, wear jewellery and use make-up and mobile phones, representations that stand in stark contrast with the neo-traditional-inspired art featured in the textbooks. Moreover, none of the women have their hair tied in a ponytail, as Lao school rules prescribe (see Figure 3).

The drawing in Figure 7 was much admired by other students in the class. When the class were asked about the artist behind this artwork, her fellow students (both boys and girls) were very quick to point her out. Although this piece of work was put on display by the teacher, it is worth pointing out that it was graded lower than that depicting women less obviously engaged in such forms of conspicuous consumptions, and lower too than the drawing of a cat and a $\operatorname{dog}$ (see Figure 6). 


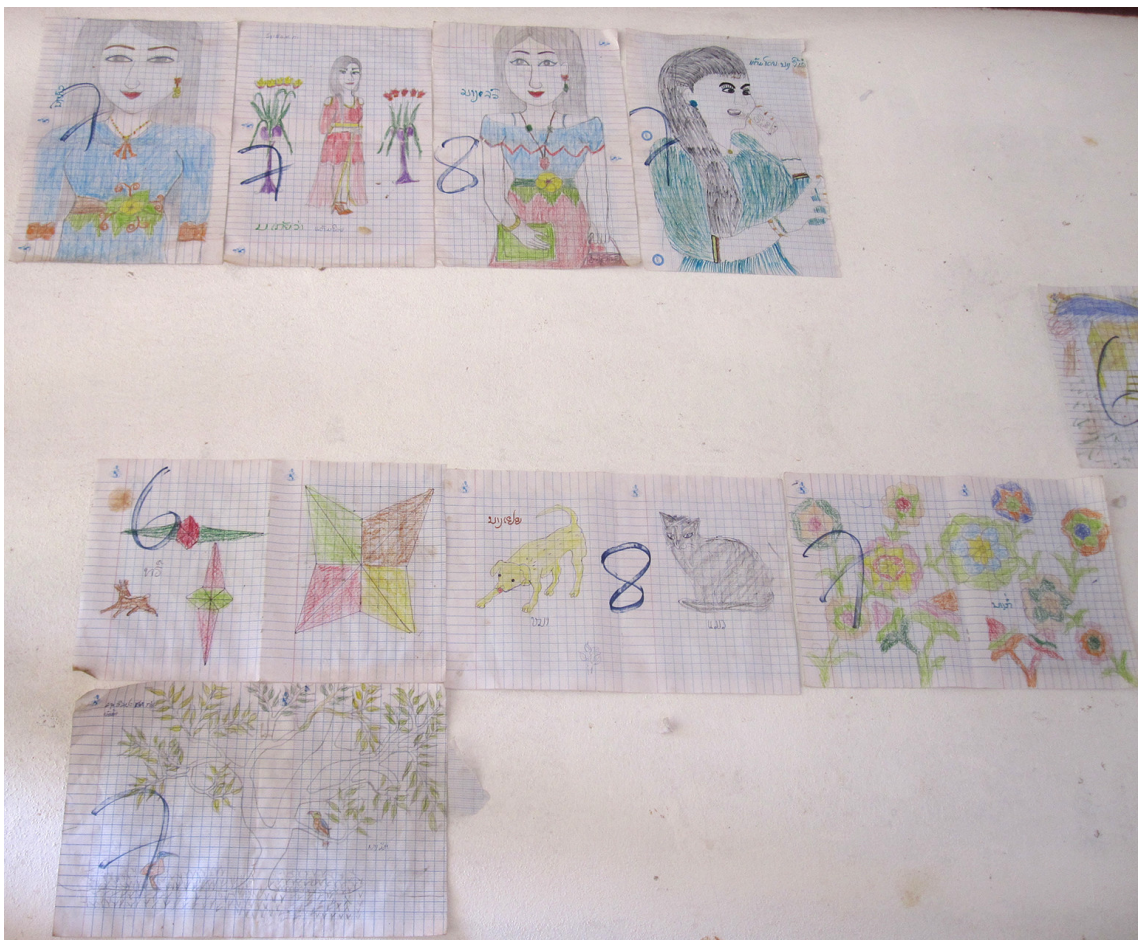

FIGURE 6 Students' artwork (Baan Nyai)

Children's sketches of a good life, as presented above, contrast with children's descriptions of a good life in (informal) interviews. When asked about their aspired occupation they typically mentioned the figure of the teacher, nurse/doctor, police officer or soldier (and, more exceptionally, district governor or architect). When probed further, children (boys and girls alike) explained their answers on the basis of a collective vision of a good life. So rather than emphasising the salaried nature of these forms of employment and the consumption this would facilitate, they would say that they wanted to become a teacher in order to educate the children of the village, become a nurse/doctor to provide care for their parents and other people in the village, join the police force or army to protect the village and/or country from thieves and bad people, etc. Going on the grounds of these interviews only would suggest that more material and individualistic notions of a good life have no place in children's ideas about the future. Yet children's artwork shows that they imagine more material and individualistic notions of a good life, too, but express these in the margins of the classroom and in a non-verbal manner. 


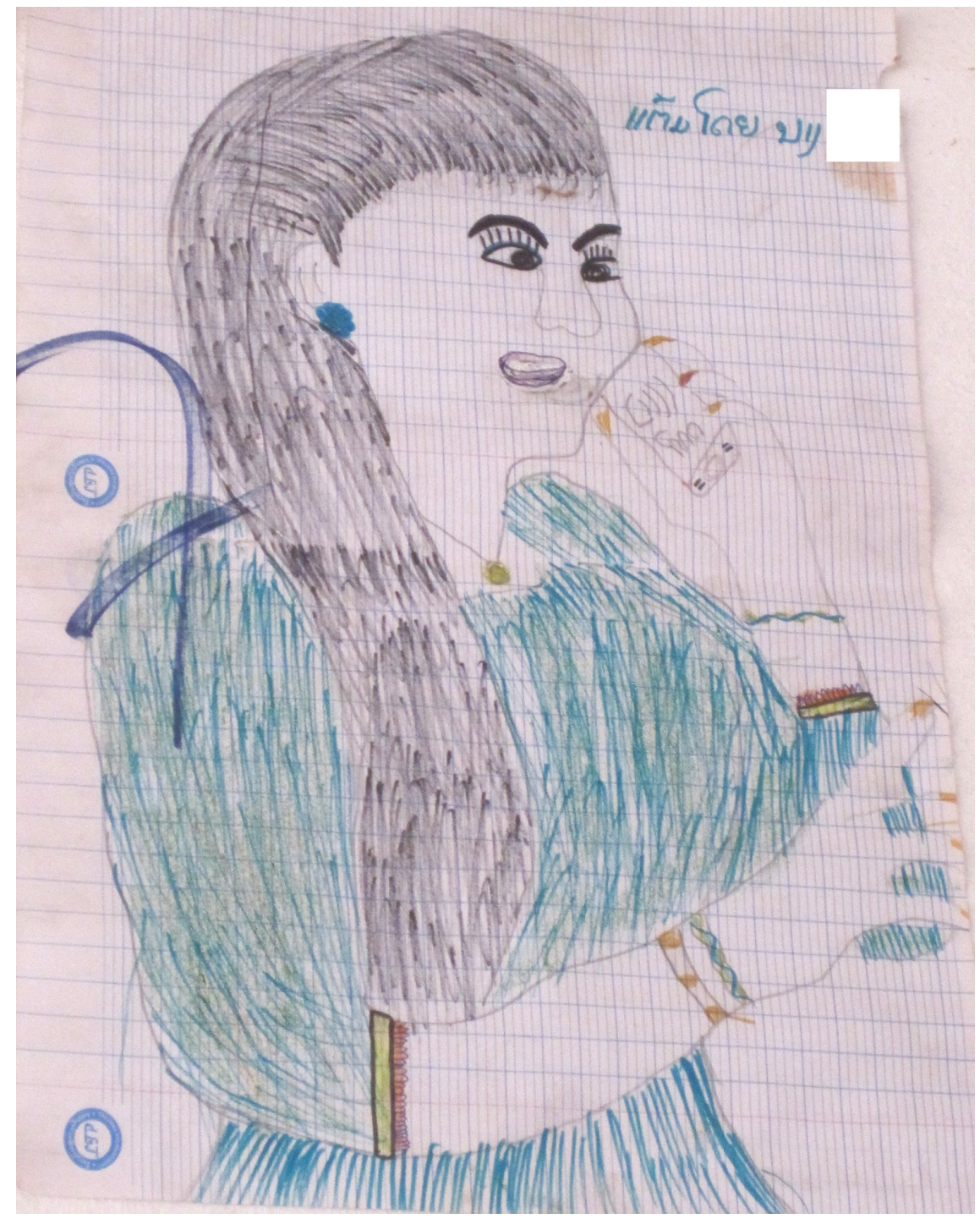

FIGURE 7 Student's articulation of a good life (Baan Nyai)

This section presents ethnographic accounts of instances observed at school that were evidently enjoyed as 'good moments' in the sense that they were enjoyable and made people feel happy. In doing so, the article contrasts a mass event (the primary school-leaving exam) with two moments of good time involving a more select group of participants (martial arts and dance). It is 
argued that these moments of good time can be read as brief instances of a good life in the present. While the joyous atmosphere around the schoolleaving exam quickly turned toxic for at least some involved, this was not observed in relation to the dance and martial arts practices. The moments of good time around the exams confirmed Berlant's assertion (2011, 27) that the efforts of staying near to what one desires wear one out, because they confront one with the limitations of one's conditions of possibility. Here, good times became toxic. Yet in the other instances described, these moments of good time stayed essentially good.

\subsection{Primary School-Leaving Exams: Good Times Turning Toxic?}

In remote rural Laos, the primary school-leaving exam constitutes a significant undertaking. The one observed by Mr Piti in 2017 involved a total of seventy-four students (coming from two different primary schools) and thirtytwo adults (including teachers, district-level officials, village representatives, etc.) organised in a range of different committees tasked with responsibilities for the various exam-related activities, including setting up the classrooms, invigilation, grading exams and preparing food. Paper sheets pinned on the wall of the school named the various committees and their members.

An official of the District Education and Sports Bureau (DESB) was assigned to personally deliver the exam script, oversee the various procedures and return to the district centre with the exam results. However, it would be a mistake to view the various activities related to the exams as ordered by the district. As the summarised fieldnotes below show, district-level guidelines at best provided a context within which villagers largely self-organised the exam and the various activities around it (compare with High 2014).

Observing the exams, Mr Piti noted that teachers and members of the exam committee were busy helping students in answering the exam questions. He also noticed how the invigilators allowed students to copy each other's answers. It was only when they noticed Piti that they told students to stop doing so. Given this awkward situation, one of the teachers from Baan Nyai approached Piti and said 'Just help them, otherwise many students will fail.' It took Piti a few seconds to realise he was not being asked to help the students, but the teacher was appealing to him to help the teachers by not reporting the practices he was observing.

Later, the district education officer charged with overseeing the exam confided to Piti that they had been practising the 'helping of students' since 2015 when Laos announced that primary education completion was made compulsory. He explained: 'That's why we have to help them, to 
complete primary school.' He continued, justifying the practice: 'A lot of effort has been put in building school infrastructure, producing educational materials, training teachers and setting up school feeding programmes in order to keep students in the school and avoid them dropping out.'

Despite these efforts to make all students pass, the students themselves were generally uncertain about the outcome of the exam. After the first day of exams an ethnic Hmong student, a girl, said she was ' $50-50^{\circ}$ ' confident that she would pass the exam. Another ethnic Hmong student, a boy, confided to Mr Piti that he feared he had not done well in the dictation part. 'The teacher read out the text very quickly and I was too scared to ask him to repeat the dictation.'

No doubt thanks to the teachers' interventions, the pass rate was indeed 100 per cent-all students had passed.

Already well before this excellent result was announced the teachers and others on the various committees were in a festive mood thanks to the jars of lao hai ${ }^{9}$ the students had offered to the exam committee. The district education officer explained 'Students bring lao hai to show their gratitude to their teachers and because they are happy to complete primary school.' With the exam writing still ongoing, the drinking took place in a small hut on the school grounds accompanied with lots of loud laughter and banter. In addition, other members of the various exam committees combined the drinking with games of petanque on the court in the school ground. Meanwhile, the newly constructed classroom for pre-primary education paid for by Plan International had been turned into a kitchen and taken over by the cooking committee. Several ducks, chickens, one dog and a goat did not survive the primary school-leaving exam.

Summarised from fieldnotes, 22 May-5 June 2017

Realising a perfect exam score, children providing teachers with home-made alcohol and enjoying some good food ensures a good time. Such instances, we would suggest, constitute moments of a good life in the present. This assertion is confirmed by the fact that a district education officer (ethnic Hmong) who worked closely with the researchers shared images of the 2019 school-leaving exam alongside the various other pictures of 'good times' that filled his Facebook timeline. When the first author reached out to him through Facebook

9 Traditional home-brew, rice-based liquor especially common in Khmu communities. 
Messenger for further details about these pictures, he confirmed they were taken at a school-leaving exam he oversaw, and pointed out that one of the photos depicted a baci ceremony organised by the village authorities for the DESB staff to celebrate the achievement and mark their hard work.

The baci ceremony, teachers helping students answer questions, sharing food and alcohol, the collective work through which the exams and festivities were realised and the complicity in the production of excellent statistics all worked to surmount the social divides across which the various transformations briefly mentioned in the introduction of this paper unfold in upland rural Laos. These include the hierarchical relations between teachers and students, unequal state-society relations and the hierarchical ethnic relations on to which they map in upland rural Laos.

In her analysis of the role of the baci ceremony in district-level governance in rural Laos, Singh (2014) notes the ambiguity in the practice of state-society relations. She explains that the levelling of inequalities enacted through the baci ceremony co-exists with hierarchical, secular village meetings that are also part of these visits by district-level officials to rural villages. Singh's point is not contested here. In fact, upon the arrival of the DESB official in the village, he called for a preparation meeting and this left no doubt about the hierarchical nature of state-society relations. However, by bringing Singh's argument in dialogue with Berlant's thesis it is clear that the collective work and festivities around the school-leaving exam had a twofold effect: it brought people nearer to the thing they desired, through recognition by seniors, becoming educated and realising perfect results from one's work, yet simultaneously it made concrete the limitations of the possibilities within - at least for some. For example, many students realised that their ability and knowledge was insufficient for passing the exam on their own. They needed the help of their teachers. Secondary school teachers were quick to complain about students coming out of primary school without basic literacy and numeracy skills. Furthermore, the alcohol that flowed between these very differently ranked and gendered educators certainly facilitated more informal interaction across social hierarchies, but not without the risk of unpleasant encounters also stimulated by alcohol and unfolding along social divides. ${ }^{10} \mathrm{It}$ is for this reason that this article suggests

10 In this specific event no such unpleasant encounters were seen. However, during an earlier visit by DESB officials it was noticed that it was the expectation that junior female volunteer teachers would accompany the district officials in beer-drinking sessions. On the surface, such drinking sessions were joyful too, yet it should be remembered that these volunteer teachers depend on district officials for getting a permanent (and salaried) teaching position, which leaves such encounters open to abuse. 
that the moments of good time observed during the school-leaving exams were deeply ambiguous as they might easily turn out to be toxic for at least some of those involved.

\subsection{Good Times that Stayed Inherently Good: Martial Arts and Dancing}

The practices around the school-leaving exam are usefully contrasted with two other practices that were observed: a martial arts activity led by the sports teacher and a dancing activity involving some of the students and teachers, both in Baan Nyai. Both practices took place at the end of a regular teaching day at the secondary school during a slot marked on the timetable as 'local curriculum. The idea behind this slot is that teachers can teach or organise activities of relevance to the specific locality in which they are working - this in contrast with the larger part of the curriculum which is nationally set.

The young male sports teacher called together a small group of male students in front of the main structure of the primary school. The boys started doing a number of martial arts. Despite the heat, the students beamed with joy, and the strict discipline conveyed by the bamboo stick the teacher carried (and threatened to use) only seemed to add to it. In contrast to the usual classroom sessions, both the students and the teacher were actively involved in the activity. Although the teacher acted as a coach and did not join in in the movements, the relation was different from what we normally observed in the classroom. The teacher didn't stay in front of the boys but moved between them; students did not wait for the instructions of the teacher but initiated their own spectacular moves and laughed loudly when something went wrong (as compared with the silence and embarrassment we would observe in the classroom in the case of mistakes).

Meanwhile, behind one of the secondary school classrooms a female teacher set up a speaker system. She connected it with her mobile phone and soon the school grounds were filled with loud music. She called together a group of female students and started practising (ethnic) Lao traditional dance. She ran through a number of hand gestures and foot positions. Here the teacher joined in too: she danced with the girls, explaining the positions and moves as she danced. Then some boys passed by and they joined in too.

After some thirty minutes the martial arts session had come to an end in the same unassuming manner as it had started. The students had also stopped dancing. However, their place had now been taken up by other teachers, both male and female. One of the teachers changed the music 
and we moved from traditional dance to line dancing. The sports teacher joined in too, as did the research team. We had fun.

Summarised from fieldnotes, Baan Nyai, March 2018

In instances like these, it is suggested, moments of good time stayed essentially good. Teacher-student relations were much more egalitarian than were ever observed in the classroom and this did not change over the course of the activity. Students practising martial arts took the liberty to initiate their own movements and enjoyed mistakes as much as success. In the case of the dance session, boys and girls and male and female teachers had a good time together without this setting up potentially problematic encounters.

The exams are an essential feature of modern mass schooling, while the two practices described above were only lightly rooted in the curriculum and involved only a few students and teachers. Furthermore, events such as the martial arts and line-dancing activities were never mentioned in any of the many interviews we conducted with students, teachers or parents (exams, or at least exam results, certainly were). Even when we asked specifically about the time allocated on the timetable for 'local curriculum' and how this was used, we learned nothing about such moments of good time. However, we do not wish to suggest that all that happened during the 'local curriculum' timeslot was experienced as 'good time' - certainly not. We also observed 'local curriculum' sessions in which nothing happened or in which teachers assigned students to clean up the school grounds, draw water for the teachers' private bathrooms or collect firewood for the teachers.

Moments of good time staying inherently good are usefully contrasted with the ideas of the good life conveyed through textbooks. Unlike the message conveyed through textbooks, the martial arts and dancing sessions were not meant to be all-inclusive. Only some students became involved, and these evidently were the talented few. The same holds for gender; no girls were involved in the martial arts activities and the dancing session initially started without boys.

\section{6}

\section{Conclusion}

In late socialist Laos, systems of ideas, and therefore the bases of notions of a good life, are in constant flux. This is perhaps truest for rural Laos, rendering rural schools a fertile space for studying diverse and shifting notions of a good life. This article has made the case that state-sanctioned ideas of a good life reach the rural populace most directly through the illustrations in school text- 
books. In these illustrations, it is acknowledged that a good life can be rural. Such a rural good life is articulated as a stable condition characterised by harmony and equality, with little attention to more individualistic and material notions of a good life revolving around consumption, which has also become a key part of being young (Taye and Huijsmans 2020) and a known manifestation of late socialism also evident in rural spaces (Huijsmans forthcoming; Huijsmans and Trần 2015). The textbook-based articulations of a rural good life are out of sync with the rapid developments that are transforming rural Laos (see also Koshcheeva 2020) which, if anything, articulate and possibly deepen the social divides the textbooks are careful to erase. We further noted the absence of upland spaces and forms of livelihood of ethnic groups inhabiting these spaces in the textbook articulations of a rural good life. Hills and mountains were certainly there in the illustrations, but featured at best as a background to images of a rural good life predominantly set in lowland, ethnic Lao spaces.

Classroom-based observation indicated that the state does not have a monopoly on the expression of ideas of a good life even in the state-space of the classroom. Children themselves were sketching out the contours of their views on a good life too. Unsurprisingly, there is a gap between the imaginaries of a good life articulated through primary school textbooks and those found in children's artwork in the margins of the classroom. It has been argued that this is a gap not only in content but also in methodological terms. Uncovering children's ideas of a good life that are different from those promoted by the school system was not easy and required going beyond oral methods.

Further, the case has been made for expanding debates on a good life in late socialism with a focus on practice. This has been done by taking seriously moments of good time that unfolded as part of the everyday practice of schooling. The instances described ethnographically were rooted differently in the organisation of mass schooling. The case of the school-leaving exam is a constituting element of it and reflects most closely the larger project of schooling. The martial arts and dancing sessions came much more loosely and selectively from the organisation of schooling but were by no means less part of it.

Three pairs of distinctions differentiate the textbook-based articulations of a good life and instances of good time: those between the regimented and the spontaneous, the future oriented and the present moment, and the ideological and the experiential. Formal organisation of education plays to the first of each of these pairs. It is at once regimented, geared towards preparing Lao young people for a late socialist future, and informed and shaped by a particular ideological view of a good life. But an analysis of education is incomplete without taking account of schooling as practice. This perspective illuminated 
an alternative and co-present practice of a good life filtering through and being produced within — and, in a sense, by — the same educational system and context. These moments of good time were characterised by spontaneity, attending to the present moment, and made good not by ideology but by the joy of the moment.

With these distinctions in mind, we are left with the questions of why all these moments of good time did not stay really good, and how moments of good time sit with the textbook articulations of a good life.

The primary school-leaving exam was a mass exercise; everybody got involved, and existing social differences were made to disappear in the name of the collective work and advancement. This moment of good time was thus similar to the good life promoted through textbooks. Yet when social inequalities resurfaced - and they inevitably did because of the mass nature of this moment of good time - things were not that good any longer, at least not for all. In Berlant's terms (2011), the limitations of the possibility within dawned. In contrast, the martial arts and dance sessions take us beyond Berlant's cruel optimism. Here, no attempt was made to be inclusive in whatever terms. This was just for the select few. Yet here the good remained really good.

These very different outcomes of moments of good time practised as part of rural schooling are reflective of the condition of late socialism more broadly. The various transformations unfolding across rural Laos deepen the already existing social divides, rendering very real the limitations of possibilities within any of the multiple systems of ideas emerging from these transformations. At the same time, such transforming and competing systems of ideas produce notions of a good life which continue to be realised by some, albeit often in deeply idiosyncratic ways. In this sense, moments of good time offer an important lesson about future-making in late socialist Laos: life can indeed be good in multiple ways, but whether it stays good for all, and if so for how long, is the question.

\section{Acknowledgments}

We are grateful for the comments from fellow workshop participants on an initial version of the paper presented at the ZiF Workshop "The Good Life in Late Socialist Asia' (Bielefeld, 16-18 September 2019). Subsequent versions of the paper have greatly benefited from the excellent feedback from the guest editors of the Special Issue and the anonymous peer reviewers. We thank them all. 


\section{References}

Ansell, N., S. Changpitikoun, A.C. Dost, C. Dungey, P. Froerer and R. Huijsmans. 2018. 'Education Systems, Aspiration and Learning in Remote Rural Settings: Project Report' (draft). London: Brunel University.

Appadurai, A. 2004. 'The Capacity to Aspire: Culture and the Terms of Recognition'. In Culture and Public Action, edited by V. Rao and M. Walton, 59-84. Stanford, CA: Stanford University Press.

Baird, I.G. 2011. 'Turning Land into Capital, Turning People into Labour: Primitive Accumulation and the Arrival of Large-Scale Economic Land Concessions in the Lao People's Democratic Republic'. New Proposals: Journal of Marxism and Interdisciplinary Critique 5(1): 10-26.

Bayly, S. 2020. "Beyond "Propaganda": Images and the Moral Citizen in Late-Socialist Vietnam'. Modern Asian Studies 54(5): 1526-1595.

Benwell, M.C. 2014. 'From the Banal to the Blatant: Expressions of Nationalism in Secondary Schools in Argentina and the Falkland Islands'. Geoforum 52: 51-6o.

Berlant, L. 2011. Cruel Optimism. Durham, NC: Duke University Press.

Blake, D.J.H., and K. Barney. 2018. 'Structural Injustice, Slow Violence? The Political Ecology of a "Best Practice” Hydropower Dam in Lao PD R'. Journal of Contemporary Asia 48(5): 808-834.

Cheney, K.E. 2007. Pillars of the Nations: Child Citizens and Ugandan National Development. Chicago: University of Chicago Press.

Christie, R. 2015. 'Millennium Development Goals (MDG s) and Indigenous Peoples' Literacy in Cambodia: Erosion of Sovereignty?' Nations and Nationalism 21(2): 250-269.

Creak, S., and K. Barney. 2018. 'Conceptualising Party-State Governance and Rule in Laos'. Journal of Contemporary Asia 48(5): 693-716.

Ducourtieux, O., J.-R. Laffort and Silinthone Sacklokham. 2005. 'Land Policy and Farming Practices in Laos'. Development \& Change 36(3): 499-526.

Dungey, C., and N. Ansell. Forthcoming. "Not All of Us Can Be Nurses”: Proposing and Resisting Entrepreneurship Education in Rural Lesotho'. Sociological Research Online.

Evans, G. 1998. The Politics of Ritual and Remembrance: Laos since 1975. Chiang Mai: Silkworm Books.

Evrard, O., andY. Goudineau. 2004. 'Planned Resettlement, Unexpected Migrations and Cultural Trauma in Laos'. Development \& Change 35(5): 937-962.

Gerber, N., and R. Huijsmans. 2016. 'From Access to Post-Access Concerns: Rethinking Inclusion in Education through Children's Everyday School Attendance in Rural Malaysia'. In Childhood, Youth and Migration: Connecting Global and Local Perspectives, edited by C. Hunner-Kreisel and S. Bohne, 203-221. Dordrecht: Springer.

High, H. 2014. Fields of Desire: Poverty and Policy in Laos. Singapore: NUS Press. 
Huijsmans, R. 2019. 'Cash, Women, and the Nation: Tales of Morality about Lao Banknotes in Times of Rapid Change'. In Money and Moralities in Contemporary Asia, edited by L.A. Hoang and C. Alipio, 241-264. Amsterdam: Amsterdam University Press.

Huijsmans, R. Forthcoming. 'Age-based Marketing Practices and Young People as Economic Actors in the Mobile Telephony Market in Provincial Vietnam'. Makara Human Behavior in Asia.

Huijsmans, R., and T.H.L. Trần. 2015. 'Enacting Nationalism through Youthful Mobilities? Youth, Mobile Phones and Digital Capitalism in a Lao-Vietnamese Borderland'. Nations and Nationalism 21(2): 209-229.

Huijsmans, R., N. Ansell and P. Froerer. 2021. 'Editorial Introduction: Development, Young People, and the Social Production of Aspirations in Young Lives'. European Journal of Development Research 33(1).

Jakimow, T. 2016. 'Clinging to Hope through Education: The Consequences of Hope for Rural Laborers in Telangana, India'. Ethos 44(1): 11-31.

Kaland, O.J. 2021. “'We Have Many Options, but They Are All Bad Options!”: Aspirations among Internal Migrant Youths in Shanghai, China'. European Journal of Development Research 33(1).

Koshcheeva, A. 202O. 'Neo-traditional Art of Post-Socialist Laos: The Entangled Temporality of the Mother-land'. Southeast of Now: Directions in Contemporary and Modern Art in Asia 4(1): 31-71.

Lall, M., and E. Vickers, eds. 20o9. Education as a Political Tool in Asia. Abingdon: Routledge.

Lopes Cardozo, M.T.A. 2012. 'Transforming Pre-service Teacher Education in Bolivia: From Indigenous Denial to Decolonisation?' Compare: AJournal of Comparative and International Education 42(5): 751-772.

Morarji, K. 2014. 'Subjects of Development: Teachers, Parents and Youth Negotiating Education in Rural North India'. European Journal of Development Research 26(2): $175^{-189 .}$

Moser, S. 2016. 'Educating the Nation: Shaping Student-Citizens in Indonesian Schools'. Children's Geographies 14(3): 247-262.

Mulkeen, A., and D. Chen, eds. 20o8. Teachers for Rural Schools: Experiences in Lesotho, Malawi, Mozambique, Tanzania, and Uganda. Washington, DC: World Bank.

Nag, S., M.J. Snowling and Y.M. Asfaha. 2016. 'Classroom Literacy Practices in Lowand Middle-Income Countries: An Interpretative Synthesis of Ethnographic Studies'. Oxford Review of Education 42(1): 36-54.

Pholsena, V. 2002. 'Nation/Representation: Ethnic Classification and Mapping Nationhood in Contemporary Laos'. Asian Ethnicity 3(2): 175-197.

RIES. 2013. Primary 1 Textbook Moral Education and The World Around Us (ฉูมฐิมบัก ริภราธเละโลภย้อมต์อธธิา). Vientiane: Research Institute for Educational Sciences (RIES) of the Ministry of Education and Sports (Lao PDR). 
RIES. 2015a. Primary 3 Texbook Moral Education and The World Around Us (ฉูมิมบัก ริกราเธะโลภง้อมต์อธธิง). Vientiane: Research Institute for Educational Sciences (RIES) of the Ministry of Education and Sports (Lao PDR).

RIES. 2015b. Primary 4 Textbook Moral Education and The World Around Us (ฉูมฐิมบัล ริภราเละโลภง้อมต์อธธิา). Vientiane: Research Institute for Educational Sciences (RIES) of the Ministry of Education and Sports (Lao PDR).

RIES. 2016. Primary 5 Textbook Moral Education and The World Around Us (ฉมริมบัด ริภราเละโลภอ้อมต์อธธิา). Vientiane: Research Institute for Educational Sciences (RIES) of the Ministry of Education and Sports (Lao PDR).

Rigg, J. 2005. Living with Transition in Laos: Market Integration in Southeast Asia. London: RoutledgeCurzon.

Rowedder, S. 2020. 'Railroading Land-linked Laos: China's Regional Profits, Laos' Domestic Costs?' Eurasian Geography and Economics 61(2): 152-161.

Sen, A. 1999. Development as Freedom. Oxford: Oxford University Press.

Singh, S. 2014. 'Religious Resurgence, Authoritarianism, and "Ritual Governance": Baci Rituals, Village Meetings, and the Developmental State in Rural Laos'. Journal of Asian Studies 73(4): 1059-1079.

Stolz, R. 2019. 'Making Aspirations Concrete: "Good Houses" and Mockery in Upland Laos'. Ethnos, doi.org/10.108o/oo141844.2019.1696864.

Suksavang Simana. 2003. Kmhmu' Livelihoods: Farming the Forest. Vientiane: Institute for Cultural Research, Ministry of Information and Culture (Lao PDR).

Tappe, O. 2007. 'A New Banknote in the People's Republic: The Iconography of the Kip and Ideological Transformations in Laos, 1957-2006'. Internationales Asienforum 38(1-2): 87-108.

Taye, F.N., and R. Huijsmans. 2020. 'Monetised Childhoods: Money and Consumption among Young Weavers in Addis Ababa, Ethiopia'. Global Studies of Childhood 10(2): 183-194.

UnICEF and MoES. 2015. 'Situational Analysis: Student Learning Outcomes in Primary Education in Lao PDR'. Vientiane: UNICEF/Ministry of Education and Sports (Lao PDR).

Villalba, U. 2013. 'Buen Vivir vs Development: A Paradigm Shift in the Andes?' Third World Quarterly 34(8): 1427-1442.

Vongvisouk, T., O. Mertz, S. Thongmanivong, A. Heinimann and K. Phanvilay. 2014. 'Shifting Cultivation Stability and Change: Contrasting Pathways of Land Use and Livelihood Change in Laos'. Applied Geography 46: 1-10.

Walker, A. 2001. 'The "Karen Consensus", Ethnic Politics and Resource-Use Legitimacy in Northern Thailand'. Asian Ethnicity 2(2): 145-162.

World Bank. 2006. World Development Report 2007. Development and the Next Generation. Washington, DC: International Bank for Reconstruction and Development/ World Bank. 